\title{
FOREWORD: THE COMMON GROWL
}

\author{
JEAN-LUC NANCY
}

Of politics, today, nothing remains.

Of politics, today, everything remains.

Nothing remains because what defined the content of the word politics has been swept away by a history that there can be no question of reviving or probably even of revisiting.

First, this was the history that saw the birth of the polis, that is to say, the form that a gathered collectivity gave itself, one governed by itself and not by a divine authority. The Greek city, like the Roman one, depended on a shattering of theocratic or tribal forms of organization (which were often interlinked), but not without retaining essential aspects of the rigid hierarchies that structured traditional societies, as well as the displacement of a part of social sacredness onto what we can (anachronistically) call civil religion.

The general design of the ancient city no longer makes any sense to us since it unraveled of itself. The polis was formed, transformed, and deformed with the movement of a civilization profoundly in flux, leaving behind the reproduction of life based solely on agriculture to initiate forms of production and commerce Marx called "pre-capitalist." The representation of another city ended up being invented, that of a God resolutely outside the world and before whom the hierarchies and forms of domination that structured society no longer obtained.

The task of making the world-in the sense of a space for circulation of sense-to which the city was supposed to respond, became divided in 
two: on the one hand, the transfiguration of the world into God's kingdom; on the other, the configuration of the world of humans. "Politics" thus became the name of a space to be invented: It will be called "Republic" (in all the successive values of the word, at least since Jean Bodin), a space for the creation of sense (of the world), whose consistency and stability (the State) are assured through sovereignty (the quality of origin and of founding "public law"). When sovereignty ceased to be identified with a figure (a royal one, for example) and became that of the "people," it adopted the task of configuring the space of this "people." This is what goes by the name of democracy.

At this point, politics suffered a profound dehiscence. On the one hand, it remained identified with the Republic and with the State, at the same time that its scope of practice and legitimacy came to be determined as the "nation"-an assumed or fashioned identity. On the other hand, preserving the traits of a figural, authoritarian, and separate organizational function (instance), it was destined to cancel its own separation and to disappear as a distinct sphere in order to re-emerge immersed in all spheres of common existence, beginning with the exercise of decision (council, direct democracy).

The separation of "politics" has neither been abolished nor really maintained. What has effectively occurred is an impregnation of all spheres of common existence (that is to say, tendentially, of existence tout court, the common of existing, both human and non-human, that with which the word communism was supposed to be charged) by infrapolitical as well as suprapolitical schemata. These involve mythical and affective representations of collective destinies (which at the same time shelter enormous techno-economic machines) or else the representation of the generalized management of comfort within the general equivalence of market value-in one way or another, a world of completeness or of indefinite saturation.

This is the point at which nothing remains of politics, and thereby everything of it remains: The question of the configuration of a space for circulation of sense (one can also say: of sense, thus of circulation without completeness) is fully posed, open, gaping.

In this opening, at least one signal flickers: All forms of completeness or of saturation, ideological or techno-economic, engender inequalitiesinhumanities, insensibilities, insanities - that are not only as onerous as those sustained by former hierarchies and forms of sacredness, but that are

viii Jean-Luc Nancy 
also henceforth clearly devoid of any appearance of natural or supernatural justification.

That is why politics subsists at least as revolt-when necessary, as a revolt against politics. "Revolt" does not mean "revolution" to the extent that this latter term has come to bear the projection either of an overturning of the basis of politics-with the conservation of its structure-or of a complete abolition of the separation of its organizational function. Neither does revolt promise as much by way of great risks, which is why it may become suspicious even of revolutionary politics. But it protests that existence is untenable if it does not open up spaces of sense; that this opening up of sense is impossible so long as what reigns instead of circulation is the pitiless circularity in which everything-amounts-to-the-same; and that this "reign" itself is devoid of any kind of glory or grace, whereas the other reign, that of the heavens, no longer flutters except exsanguinate and grimacing.

Subsisting as revolt, politics perhaps no longer subsists at all; but perhaps it is not necessary to think in terms of subsistence, of remainder, or of survival. It is above all necessary not to wait for anything from "politics," as if it were the mysterious reservoir of who knows what hidden resource of meaning.

Revolt still denounces "the spirit of a world without spirit," even if it does not intend these words entirely in the same way. Without spirit: not without "spirituality" but without the brio (vif) of signs and acts by which, alone, one exists.

Revolt, however, does not make clear what the élan (vif) of an existence open to its possibilities might be. Revolt does not discourse, it growls (gronde). What does "growl" mean? It's almost an onomatopoeia. It means to grunt, bellow, and roar. It means to yell together, to murmur, mumble, grouse, become indignant, protest, become enraged together. One tends to grumble alone, but people growl in common. The common growl is a subterranean torrent: It passes underneath, making everything tremble.

Translated by Steven Corcoran 
This page intentionally left blank 
THE COMMON GROWL 
This page intentionally left blank 